\begin{tabular}{|c|c|c|c|c|c|c|}
\hline \multirow[t]{2}{*}{ B-cell subsets } & \multicolumn{2}{|l|}{1 group $(n=27)$} & \multicolumn{2}{|l|}{2 group $(n=26)$} & \multicolumn{2}{|c|}{ Control group $(n=29)$} \\
\hline & Cells, $10^{9} / л$ & $\begin{array}{l}\text { Persentage, } \\
\%\end{array}$ & , Cells, $10^{9} / \pi$ & $\begin{array}{l}\text { Persentage, } \\
\%\end{array}$ & $\begin{array}{l}\text { Cells, } \\
10^{9} / \pi\end{array}$ & $\begin{array}{l}\text { Persentage, } \\
\%\end{array}$ \\
\hline B-cell [CD19+] & $0,144[0,1 ; 0,21]$ & $\begin{array}{l}9,1 \\
{[7,5-10,9]}\end{array}$ & $\begin{array}{l}0,105[0,1- \\
0,2]^{\star \star}\end{array}$ & $\begin{array}{l}8,35 \\
{[6-10,2]}\end{array}$ & $\begin{array}{l}0,2 \\
{[0,1-0,2]}\end{array}$ & $\begin{array}{l}8,5 \\
{[7,2-11,0]}\end{array}$ \\
\hline B-memory cell [CD19+CD27+] & $\begin{array}{l}0,003[0,00166 \\
0,0044]\end{array}$ & $2,1[1,6-3,1]$ & $\begin{array}{l}0,003]^{*} \\
0,0015[0,\end{array}$ & $\begin{array}{l}1,25[0,9- \\
1,7]^{\star}, \star \star\end{array}$ & $\begin{array}{l}0,003 \\
{[0,001-} \\
0,007]\end{array}$ & $2,2[1,1-3,0]$ \\
\hline $\begin{array}{l}\text { Switched B-cells } \\
\text { [CD19+CD27+lgD-] }\end{array}$ & $\begin{array}{l}0,0187 \\
{[0,0133-0,0289]}\end{array}$ & $\begin{array}{l}16 \\
{[9,3-18,4]}\end{array}$ & $\begin{array}{l}0,01 \\
{[0,005-0,02]}\end{array}$ & $\begin{array}{l}6,8[3,6- \\
11,6]^{\star}, \star \star\end{array}$ & $\begin{array}{l}0,02 \\
{[0,01-} \\
0,04]\end{array}$ & $\begin{array}{l}12,8 \\
{[9,3-17,0]}\end{array}$ \\
\hline Non-switched B-cells [CD19+CD27+lgD+] & $\begin{array}{l}0,0073 \\
{[0,00619-0,0122]}\end{array}$ & $5,9[3,6-9,7]$ & $\begin{array}{l}] 0,009 \\
{[0,006-0,01]}\end{array}$ & $\begin{array}{l}7,45 \\
{[5,1-11,4]^{\star *}}\end{array}$ & $\begin{array}{l}0,01 \\
{[0,005-} \\
0,02]\end{array}$ & $\begin{array}{l}7,4 \\
{[3,7-11,1]}\end{array}$ \\
\hline $\begin{array}{l}\text { Double negative D-cells } \\
\text { [CD19+CD27-lgD-] }\end{array}$ & $0,021[0,011-0,028$ & $\begin{array}{l}\text { 3]14 } \\
{[9,6-19,5]}\end{array}$ & $0,02[0,01-0,03]$ & $\begin{array}{l}15,05 \\
{[11,9-18,1]}\end{array}$ & $\begin{array}{l}0,02 \\
{[0,01-} \\
0,02]\end{array}$ & $\begin{array}{l}13,3 \\
{[7,1-19,3]}\end{array}$ \\
\hline Naive B-cells & $0,076[0,063-0,13]$ & $\begin{array}{l}61,6 \\
{[52,9-68,8]}\end{array}$ & $0,095[0,07-0,1]$ & $\begin{array}{l}] 70,85[62,5- \\
75,6]\end{array}$ & $\begin{array}{l}-0,1 \\
{[0,06-0,1}\end{array}$ & $\begin{array}{l}64,7 \\
1][57,6-72,4]\end{array}$ \\
\hline$[\mathrm{CD} 19+\mathrm{CD} 27-\operatorname{lgD}+]$ & & & & & & \\
\hline $\begin{array}{l}\text { Transitioning B-cells } \\
\text { [CD19+CD38++CD10+lgD+CD27-] }\end{array}$ & $\begin{array}{l}0,000424 \\
{[0,000162-} \\
0,000624]^{*,},\end{array}$ & $0,2[0,1-0,4]$ & $0[0-0,0001]$ & $0[0-0,1]$ & $\begin{array}{l}0,0001 \\
{[0-} \\
0,0003]\end{array}$ & $0,1[0-0,1]$ \\
\hline Plasmoblasts & $\begin{array}{l}0,00071[0,00023- \\
0,00129]^{*, * *},\end{array}$ & $\begin{array}{c}-0,4[0,3- \\
0,8]^{\star},{ }^{\star *}\end{array}$ & $\begin{array}{l}0,0003 \\
{[0,00007-}\end{array}$ & $\begin{array}{l}0,15 \\
{[0,1-0,3]}\end{array}$ & $\begin{array}{l}0,0002 \\
{[0,0001-}\end{array}$ & $\begin{array}{l}0,1[0,1-0, \\
-2]\end{array}$ \\
\hline [CD19+CD38+++CD27+lgD-CD20-] & & & $0,0004]$ & & $0,0004]$ & \\
\hline Plasmocytes [CD19+CD38+] & $\begin{array}{l}0,000262 \\
{[0,000106-} \\
0,000414]^{*}\end{array}$ & $0,1[0,1-0,3]$ & $\begin{array}{l}0,0001 \\
{[0-0,0002]}\end{array}$ & $0,1[0-0,1]$ & $\begin{array}{l}0,0001 \\
{[0,00-} \\
0,0002]\end{array}$ & $\begin{array}{l}0,1 \\
{[0,05-0,1]}\end{array}$ \\
\hline
\end{tabular}

Data presented as median and interquartile range. ${ }^{*}$ - differences to control group were observed, $p<0,05 .{ }^{* \star}$ - differences between pts. goups were observed, $p<0,05$.No significant difference between T-cell subsets was found.In comparison with healthy individuals, pts. with early RA had increased levels of switched B-memory cells, transitioning B-cells and plasmoblasts, the opposite was observed in progressed RA pts with addition of decrease in B-memory cells.

Acknowledgments: The reported study was funded by RFBR, project 19-315-90090

Disclosure of Interests: None declared

DOI: 10.1136/annrheumdis-2021-eular.3816

\section{AB0069 ANTIBODIES AGAINST PHOSPHORYLCHOLINE AS PROTECTION MARKERS IN AUTOIMMUNITY, ATHEROSCLEROSIS, CARDIOVASCULAR DISEASE AND CHRONIC INFLAMMATION - IMPLICATIONS FOR TREATMENT}

\section{J. Frostegård ${ }^{1} .{ }^{1}$ Karolinska Institutet, IMM, Stockholm, Sweden}

Background: Autoimmunity, atherosclerosis and cardiovascular disease (CVD) are chronic inflammatory conditions and represent a major part of global burden of morbidity and also mortality. The immune system plays an important role in these conditions. Further, the risk of CVD and atherosclerosis is raised in several autoimmune conditions, where SLE is an important example. Its major cause, atherosclerosis (where activated immune competent cells producing cytokines are abundant), for example, active and passive immunization can influence the degree of atherosclerosis in animal experiments, but no treatment developed to specifically ameliorate inflammation is presently available. The cause of the chronic inflammation and immune activation in atherosclerosis has not been fully defined, and there are different, non-mutually exclusive and potentially synergistic possibilities including oxidized LDL (oxLDL) heat shock proteins (HSP) and infections. We focused on the lipid moiety in OxLDL, especially phosphorylcholine $(P C)$ which is a small hapten, immunogenic when exposed and reported that OxLDL's immunological effects is to some extent caused by PC. Antibodies against PC (anti-PC) are abundant, about $5-10 \%$ of circulating IgM is IgM anti-PC.

This is thus a theranostic concept, combining novel risk markers with possible underlying mechanisms and potentially immunization to raise anti-PC.

Objectives: We reported that anti-PC, especially IgM (and Ig1) anti-PC is negatively associated with atherosclerosis progress, CVD (including both MI and stroke) in different populations, and also with autoimmune diseases, especially systemic rheumatic diseases as SLE. Potential mechanisms include anti-inflammatory effects, inhibition of uptake of OxLDL in the vascular wall, promotion of $T$ regulatory cells, inhibition of cell death, and increased clearance of dead cells. Methods: We have used a combination of experimental and translational/clinical studies.

Results: Based on our findings, we have proposed a novel hypothesis which is a development of the hygiene/old friends-hypothesis, namely that low exposure to microorganisms as nematodes, parasites and some bacteria which from an evolutionary point of view has been with humanity for millions of years, leads to low levels of the antibodies described and a lack of ability to prevent autoimmune conditions. Indeed, individuals from Kitava, New Guinea leading a traditional life as hunter-gatherers and horticulturalists appear not to have CVD or rheumatic disease, but strikingly high anti-PC levels.

Conclusion: anti-PC could be a novel factor protecting against rheumatic disease.

Disclosure of Interests: Johan Frostegård Shareholder of: I am named as inventor on patents related to antibodies against phosphorylcholine, Grant/ research support from: From Amgen, related to PCSK9 and inflammation, unrelated to this topic

DOI: 10.1136/annrheumdis-2021-eular.4317

\section{Spondyloarthritis - aetiology, pathogenesis and animal models}

\begin{tabular}{|l|l}
\hline AB0070 & ROLE OF VASPIN IN ATHEROSCLEROTIC \\
DISEASE AND CARDIOVASCULAR RISK IN AXIAL \\
SPONDYLOARTHRITIS
\end{tabular}

J. Rueda-Gotor ${ }^{1}$, R. López-Mejías ${ }^{1}$, S. Remuzgo-Martínez ${ }^{1}$, V. Pulito Cueto', A. Corrales ${ }^{1}$, L. Lera-Gómez¹, V. Portilla', I. González-Mazón ${ }^{1}$, R. Blanco', R. Expósito ${ }^{2}, \mathrm{C} . \mathrm{Mata}^{2}$, J. Llorca ${ }^{3}$, V. Hernández-Hernández ${ }^{4}$, C. RodríguezLozano $^{5}$, N. Barbarroja Puerto ${ }^{6}$, R. Ortega Castro ${ }^{6}$, N. García Castañeda C. Fernández-Carballido ${ }^{8}$, M. P. Martínez-Vidal ${ }^{9}$, D. Castro-Corredor ${ }^{10}$, J. Anino-Fernández ${ }^{10}$, D. Peiteado ${ }^{11}$, C. Plasencia ${ }^{11}$, E. Galindez ${ }^{12}$, M. L. García Vivar $^{12}$, O. Gualillo ${ }^{13}$, J. C. Quevedo-Abeledo ${ }^{5}$, S. Castañeda ${ }^{7}$, I. FerrazAmaro $^{4}$, M. A. González-Gay ${ }^{1,14,15}$, F. Genre ${ }^{1} .^{1}$ IDIVAL, Hospital Universitario Marqués de Valdecilla, Research Group on Genetic Epidemiology and Atherosclerosis in Systemic Diseases and in Metabolic Diseases of the Musculoskeletal System, Santander, Spain; ${ }^{2}$ Hospital Comarcal de Laredo, Rheumatology Department, Laredo, Spain; ${ }^{3}$ University of Cantabria, and CIBER Epidemiología y Salud Pública (CIBERESP), School of Medicine, Santander, Spain; ${ }^{4}$ Hospital Universitario de Canarias, Rheumatology Division, Santa Cruz de Tenerife, Spain; ${ }^{5}$ Hospital Universitario de Gran Canaria Dr. Negrín, Rheumatology Department, Las Palmas de Gran Canaria, Spain; ${ }^{6}$ Hospital Reina Sofía, Maimonides Institute for Research in Biomedicine of Cordoba (IMIBIC), University of Cordoba, Rheumatology Department, Córdoba, Spain; ${ }^{7}$ Hospital de La Princesa, IIS-Princesa, Rheumatology Department, Madrid, Spain $;{ }^{8}$ Hospital Universitario de San Juan, Rheumatology Department, Alicante, Spain; ${ }^{9}$ Hospital General Universitario de Alicante, Rheumatology Department, Alicante, Spain; ${ }^{10} \mathrm{Hospital}$ General Universitario de Ciudad Real, Rheumatology Department, Ciudad Real, Spain; ${ }^{11}$ Hospital Universitario La Paz-IdiPaz, Rheumatology Department, Madrid, Spain; ${ }^{12}$ Hospital Universitario Basurto, Rheumatology Department, Bilbao, Spain; ${ }^{13}$ SERGAS 
and IDIS, NEIRID Lab, Research Laboratory 9, Santiago University Clinical Hospital, Santiago de Compostela, Spain; ${ }^{14}$ University of Cantabria, School of Medicine, Santander, Spain; ${ }^{15}$ University of the Witwatersrand, Cardiovascular Pathophysiology and Genomics Research Unit, School of Physiology, Faculty of Health Sciences, Johannesburg, South Africa

Background: Vaspin is a novel anti-inflammatory adipokine associated with cardiovascular (CV) disease and inflammation in chronic inflammatory conditions different from axial spondyloarthritis (axSpA). ${ }^{1}$ Given the high incidence of CV disease (mainly due to accelerated atherosclerosis) exhibited by axSpA patients, ${ }^{2}$ we wondered if vaspin could also be a key molecule in this process. However, data on the role of vaspin regarding atherosclerotic disease in the context of axSpA is scarce. ${ }^{3}$

Objectives: To evaluate the implication of vaspin, at the genetic and serological level, in subclinical atherosclerosis and CV risk in axSpA.

Methods: 510 patients who fulfilled the ASAS criteria for axSpA ${ }^{4}$ were included in this study. Carotid ultrasound (US) was performed to evaluate the presence of subclinical atherosclerosis. Three vaspin gene variants (rs2236242 T/A rs7159023 G/A and rs35262691 T/C) were genotyped by TaqMan probes. Serum vaspin levels were assessed by Enzyme-Linked ImmunoSorbent Assay. Analysis was performed using a statistical software.

Results: Serum vaspin levels were significantly higher in female patients than in males and also in obese patients when compared to those with normal weight $(p<0.05)$. At the genetic level, we disclosed that the minor allele of rs2236242 (A) was associated with lower serum vaspin levels in axSpA while the rs7159023 minor allele $(A)$ was linked to higher serum levels $(p<0.05)$ When the three polymorphisms assessed were combined conforming haplotypes, we disclosed that the TGC haplotype related to high serum levels of vaspin $(p=0.01)$. However, no statistically significant association was observed between vaspin and markers of subclinical atherosclerosis, both at the genetic and serological level.

Conclusion: Our results revealed that vaspin is linked to $\mathrm{CV}$ risk factors that may influence on the atherosclerotic process in axSpA. Additionally, we disclosed that serum vaspin concentration is genetically modulated in a large cohort of patients with axSpA.

REFERENCES:

[1] Adv Exp Med Biol. 2019;1111:159-88.

[2] Front Med (Lausanne). 2018;5:62.

[3] Braz J Med Biol Res. 2016;49(7):e5231.

[4] Ann Rheum Dis. 2009;68(2):ii1-44

Acknowledgements: Personal funds: RL-M: Miguel Servet type I CP16/00033 (ISCIII-ESF); SR-M: RD16/0012/0009 (ISCIII-ERDF); VP-C: PREVAL18/01 (IDIVAL); LL-G: INNVAL20/06 (IDIVAL).

Disclosure of Interests: Javier Rueda-Gotor: None declared, Raquel López-Mejías: None declared, Sara Remuzgo-Martínez: None declared, Verónica Pulito Cueto: None declared, Alfonso Corrales: None declared, Leticia Lera-Gómez: None declared, Virginia Portilla: None declared, Iñigo González-Mazón: None declared, Ricardo Blanco Speakers bureau: Abbvie, Pfizer, Roche, Bristol-Myers, Janssen and MSD, Consultant of: Abbvie, Pfizer, Roche, Bristol-Myers, Janssen and MSD, Grant/research support from: Abbvie, MSD and Roche, Rosa Expósito: None declared, Cristina Mata: None declared, Javier Llorca: None declared, Vanessa Hernández-Hernández: None declared, Carlos Rodríguez-Lozano: None declared, Nuria Barbarroja Puerto: None declared, Rafaela Ortega Castro: None declared, Noelia García Castañeda: None declared, Cristina Fernández-Carballido: None declared, Maria Paz Martínez-Vidal: None declared, David Castro-Corredor: None declared, Joaquín Anino-Fernández: None declared Diana Peiteado: None declared, Chamaida Plasencia: None declared, E Galindez: None declared, María L. García Vivar: None declared, Oreste Gualillo: None declared, Juan Carlos Quevedo-Abeledo: None declared, Santos Castañeda: None declared, Iván Ferraz-Amaro: None declared, Miguel A González-Gay Speakers bureau: Pfizer, Abbvie, MSD, Grant/research support from: Pfizer, Abbvie, MSD, Fernanda Genre: None declared DOI: 10.1136/annrheumdis-2021-eular.839

\section{$\mathrm{AB} 0071$ \\ RELATIONSHIP BETWEEN PRO-INFLAMMATORY CYTOKINE AND ATHEROGENIC INDEXES IN AXIAL RADIOGRAPHIC SPONDYLOARTHRITIS}

K. Ben Ali ${ }^{1}$, M. Slouma ${ }^{1}$, L. Kharrat ${ }^{1}$, A. Tezeghdenti ${ }^{2}$, R. Dhahri ${ }^{1}$, E. Ghazouani ${ }^{2}$, I. Gharsallah ${ }^{1}$, L. Metoui ${ }^{1}$, B. Louzir ${ }^{1} .{ }^{1}$ The Military Hospital of Tunis, Rheumatology, Tunis, Tunisia; ${ }^{2}$ The Military Hospital of Tunis, Immunology, Tunis, Tunisia

Background: The cardiovascular burden in inflammatory rheumatic diseases is well recognized. This burden has been reported in spondyloarthritis. Atherogenic indexes are known with their role of predicting cardiovascular risk.

Objectives: The aim of our study was to determine the relation between pro-inflammatory cytokines and atherogenic indexes in spondyloarthritis.
Methods: We performed a cross sectional study including 38 patients with spondyloarthritis according to ASAS criteria. For each patient we measured interleukin (IL)1, IL6, IL17, IL23 and tumor necrosis factor (TNF) alpha, total Cholesterol (CT), Triglycerides (TG), High density lipoprotein Cholesterol (HDLc) and Low density lipoprotein cholesterol (LDLC). We also calculated the following ratios: CT/HDLc, TG/HDLc, LDLc/HDLc, and LogTG/HDLc.

Disease activity was measured using ASDAS (Ankylosing Spondylitis Disease Activity Score) and BASDAI (Bath Ankylosing Spondylitis Disease Activity Index). Statistical analysis was performed using IBM SPSS Statistics 25.

Results: The mean age were $45.4 \pm 12.5$ years. There were 33 Male (sex ratio were 6.6)

The mean C-reactive protein(CRP) were $29.6 \pm 40.34 \mathrm{mg} / \mathrm{L}$, mean erythrocyte sedimentation rate(ESR) were $41 \pm 33.9 \mathrm{~mm}$

The mean ASDASCRP, BASDAI were $2.8 \pm 1.24,3.7 \pm 2.12$, respectively.

Active disease were noted in $68 \%$ of patients using ASDASCRP score.

The mean IL1, IL6, IL17, IL23, TNF alpha were $11.6 \pm 25 \mathrm{pg} / \mathrm{ml}, 15.4 \pm 45.9 \mathrm{pg} / \mathrm{ml}$ $84.6 \pm 77.9 \mathrm{pg} / \mathrm{ml}, 15.3 \pm 15.26 \mathrm{pg} / \mathrm{ml}, 25.3 \pm 47.9 \mathrm{pg} / \mathrm{ml}$ respectively.

The mean CT,HDLc,LDLc, TG were $4.47 \pm 0.93 \mathrm{mmol} / \mathrm{l}, 1.09 \pm 0.3 \mathrm{mmol} / \mathrm{L}$ $2.77 \pm 0.78 \mathrm{mmol} / \mathrm{L}, 1.29 \pm 0.54 \mathrm{mmol} / \mathrm{L}$ respectively.

The mean CT/HDLc, TG/HDLc, LDL/HDLc, LogTG/HDLc were $4.28 \pm 1.26$ $1.22 \pm 0.6,2.7 \pm 1.06,0.03 \pm 0.23$, respectively.

Correlations were found between TG/HDLC ratio and IL1 $(p<0.01, r=0.515)$, IL6 $(p<0.05 ; r=0.407)$, Log TG/HDLc and IL1 $(p<0.05, r=0.369)$, and IL6 $(p<0.05$ $r=0.333$ )

However, no correlations were noted between atherogenic indexes and IL7, IL17, IL23, TNFalpha.

Conclusion: Our study showed a correlations between atherogenic indexes and both IL1 and IL6.

These findings suggests that serum IL- 6 and IL1 levels in spondyloarthritis contribute to the development of cardiovascular disease atherosclerosis.

REFERENCES:

[1] Lau et al. Role of Adipokines in Cardiovascular Disease. Circ J. 2017; 81(7): 920-8.

Disclosure of Interests: None declared

DOI: 10.1136/annrheumdis-2021-eular.1281

$\mathrm{AB} 0072$

SERUM AMYLOID A PROTEIN (SAA) IN ANKYLOSING SPONDYLITIS AND THE RELATIONSHIP WITH SYSTEMIC INFLAMMATION

K. Sakharova ${ }^{1}$, M. Cherkasova ${ }^{1}$, S. Erdes ${ }^{1} .{ }^{1}$ V.A. Nasonova Scientific Research Institute of Rheumatology, Spondyloarthritis and PsA, Moscow, Russian Federation

Background: Serum amyloid A protein (SAA) likely has a critical role in control and possibly propagation of the primordial acute phase response and is the precursor of AA amyloid fibrils. Prolonged elevations in SAA are the major inciting factor for AA amyloidosis developing in chronic inflammatory diseases. In Russia $2-4 \%$ of patients with ankylosing spondylitis (AS) have secondary (AA) amyloidosis.

Objectives: To study the level of SAA in AS its relationship with indicators of disease activity.

Methods: 124 patients with AS (according to mNYC 1984) 70 men, 54 women, of whom HLA B 27 positive $91.1 \%$ mean age 38.1 ( \pm 12.9 ), age at the onset of the disease $23.5( \pm 9.9)$ consecutively admitted to the clinic of the Research Institute rheumatology from February to November 2020. In addition to the standard examination (the median CRP $6.7 \mathrm{mg} / \mathrm{l}[1.4 ; 24.9]$, ESR $13 \mathrm{~mm} / \mathrm{h}$ [7;27], SAA was studied in all patients by the nephelometric method

Results: The median SAA in 124 patients was $12.5 \mathrm{mg} / \mathrm{l}[4 ; 71.6]$. Among them $31 \%$ had normal SAA level $(<5 \mathrm{mg} / \mathrm{l})$, and $69 \%$ - more than $5 \mathrm{mg} / \mathrm{l}$. In $21(17.5 \%)$ cases, the level of SAA was increased at normal CRP levels, and only in 2 cases an increase in the level of CRP at normal SAA levels; 50 patients $(40.3 \%)$ with normal ESR had elevated SAA levels, and 7 (5.6\%) - ESR exceeded the upper limits of the norm with normal SAA levels. Comparison of the average values of the levels of SAA, CRP, ESR in men and women did not reveal significant differences between them. The SAA level was weakly correlated with ESR $(r=0.2$ $p=0.002)$ and BASDAI $(r=0.3 ; p=0.002)$, moderately with ASDAS-CRP $(r=0.5$ $r<0.0001)$, but showed a strong association with CRP $(r=0.80 ; p<0.00001)$ Patients with elevated SAA levels $(>5 \mathrm{mg} / \mathrm{l})$ had a shorter disease duration (10 and 12 year; $\mathrm{p}<0.0004$ ), higher ASDAS-CRP (2.9 and $2.4 ; \mathrm{p}<0.003$ ), blood CRP level (14.6 and $1.3 ; p<0.00001)$, and significantly more peripheral arthritis $(60 \%$ and $39 \% ; p<0.05)$ than patients with normal indicators.

Conclusion: The level of SAA correlates well with indicators of AS activity, especially with the level of CRP, and can be used as an alternative indicator of disease activity.

Disclosure of Interests: None declared

DOI: 10.1136/annrheumdis-2021-eular.1782 